практичній діяльності, в пошуковій і творчій активності, в емоційній насиченості буття, у визнанні іншими людьми й спілкуванні 3 ними, а також відповідні до цих потреб інтелектуальні здібності людини;

2) зміст навчання будується відповідно до комплексу дидактичних цілей;

3) види навчальної діяльності, закладені у змісті, спрямовуються на набуття досвіду в пізнавальній, практичній, творчо-пошуковій, ціннісно-смисловій, комунікативній діяльності учнів.

Виокремлені компоненти змісту розгортаються концентрично (уточнюються, поглиблюються й узагальнюються) протягом всього вивчення математики у старшій школі.

Підсумовуючи, варто наголосити на тому, що компонентна побудова змісту навчання математики передусім передбачає формування стійких систематизованих знань основ науки, вияв переваг предметної структури навчання, створення оптимальних умов освіти, виховання i розвитку особистості учнів в напрямку професійної спрямованості і в перспективі має набути фіксації в навчальних планах і програмах та, відповідно, бути відображеною у змісті шкільних підручників.

\title{
Література
}

1. Бурда М. Гуманістична орієнтація змісту підручників з математики / Михайло Бурда // Підготовка майбутнього вчителя природничих дисциплін в умовах моделювання освітнього середовища: [збірник укладено за матер. міжнародної науково-практичної конференції] / кол. авт. - Полтава : АСМI, 2004. - С. 55-58. 2. Бурда М. І. Зміст шкільної математичної освіти як предмет методичного дослідження / М. І. Бурда // Педагогічні засади формування гуманістичних цінностей природничої освіти, її спрямованість на розвиток особистості: [збірник матеріалів міжнародної науково-практичної конференції]. - Полтава : ACMI, 2003. - С. 15-16. 3. Гончаренко С. У. Методика як наука / С. У. Гончаренко. Хмельницький : Вид-во ХГПК, 2000. - 30 с. 4. Дидактика современной школы: [пособие для учителей] / Б. С. Кобзарь, Г. Ф. Кумарина, Ю. А. Кусый и др.; под ред. В. А. Онищука. - Київ : Рад. шк., 1987. - 351 с. 5. Краевский В. В. Проблемы научного обоснования обучения / В. В. Краевский. - Москва : Педагогика, 1977. - 264 с. 6. Леднев В. С. Содержание образования / В. С. Леднев. - Москва : Высшая школа, 1989. - 360 с. 7. Педагогический энциклопедический словарь / гл. ред. Б. М. Бим-Бад / ред. кол. М. М. Безруких, В. А. Болотов, Л. С. Глебова и др. - Москва : Большая Российская энциклопедия. - 2003. - 528 с. 8. Ситаров В. А. Дидактика: [учебное пособие для студ. высш. пед. учеб. заведений] / В. А. Ситаров; под ред. В. И. Сластенина. - Москва : Издательский центр «Академия», 2002. 368 с. 9. Скаткин М. Н. Содержание общего среднего образования : Проблемы и перспективы / М. Н. Скаткин, $\quad$ В. В. Краевский. - Москва : Знание, $1981 .-96$ с. 10. Хуторской А. В. Современная дидактика : [ученик для вузов] / Андрей Викторович Хуторской. - Санкт-Петербург : Питер, 2001. - 544 с.

УДК 37.015.31:78

Ірина Могілей

\section{ШЛЯХИ ФОРМУВАННЯ ДУХОВНИХ ПОТРЕБ УЧНІВ СЕРЕДНІХ КЛАСІВ ЗАСОБАМИ КОМПЛЕКСУ МИСТЕЦТВ НА УРОКАХ МУЗИЧНОГО МИСТЕЦТВА}

Могілей І. В. Шляхи формування духовних потреб учнів середніх класів засобами комплексу мистецтв на уроках музичного мистецтва. 
У статті розглядається проблема духовного виховання в теорії i практиці загальноосвітньої школи. Автор наголошує на актуальності і значущості окресленого напрямку музичної педагогіки, аналізує основні поняття, пропонує можливі шляхи формування духовних потреб учнів середніх класів з використанням комплексу мистецтв.

Ключові слова: духовні потреби, духовність, духовний світ, музична педагогіка, комплекс мистецтв, урок музичного мистецтва, шляхи формування духовних потреб.

Могилей И. В. Пути формирования духовных потребностей учащихся средних классов средствами комплекса искусств на уроках музыкального искусства.

В статье рассматривается проблема духовного воспитания в теории и практике общеобразовательной школы. Автор подчеркивает актуальность и значимость указанного направления музыкальной педагогики, анализирует основные понятия, предлагает возможные пути формирования духовных потребностей учащихся средних классов с использованием комплекса искусств.

Ключевые слова: духовные потребности, духовность, духовный мир, музыкальная педагогика, комплекс искусств, урок музыкального искусства, пути формирования духовных потребностей.

Mogiley I. V. Ways of spiritual needs formation of middle school students by means of the art complex at the music lessons.

The problem of spiritual education in the theory and practice of comprehensive schools is concidered. The author emphasizes the relevance and importance of this direction of music pedagogy, examines the basic concepts, and suggests possible ways of spiritual needs formation of middle school students using the art complex.

Key words: spiritual needs, spirituality, spiritual world, music pedagogy, the complex of art, a lesson in musical art, ways of spiritual needs formation.

Соціально-психологічна ситуація, яка склалася в сучасному суспільстві, характеризується своєрідною кризою особистості, що виявляється як криза їі духовності, моральності, яка виникла внаслідок втрати духовно-моральних цінностей. Оскільки показником духовності людини, пусковим механізмом ï життєдіяльності, усталеною основою вибіркової поведінки постають потреби, то одним з основних завдань навчання і виховання в загальноосвітній школі має бути формування духовних потреб школярів. Достатньо важливим його аспектом постає музичне мистецтво.

Задля розв’язання окресленої проблеми важливий пошук нових та сучасних засобів. Саме таким засобом педагогічного впливу на учнів в умовах загальноосвітньої школи $€$ використання комплексу мистецтв, який сприяє всебічному й глибокому естетичному сприйняттю різноманіття навколишньої дійсності, формує духовну потребу в постійному спілкуванні зі світом прекрасного. Водночас існують суперечності між великим виховним потенціалом музичного мистецтва та обмеженим його застосуванням у практиці роботи 3 учнями середніх класів; потребою розуміння сутності духовних потреб й невизначеністю розроблення цього складного особистісного утворення; доцільністю теоретичного обгрунтування й використання комплексу мистецтв як засобу формування духовних потреб школярів. Визначені суперечності складають сутність обраної нами проблеми.

Meта статmі - висвітлення можливих шляхів формування духовних потреб учнів середньої вікової категорії 3 використанням комплексу мистецтв на уроках 
музичного мистецтва.

Проблема духовного виховання розглядається досить грунтовно в дослідженнях відомих філософів, психологів, педагогів (М. Бережний, Б. Генкін, М. Каган, Л. Коган, Л. Печко, І. Фролов, Ю. Шаров; Ф. Герцберг, Д. МакКеланд, А. Маслоу, К. Обухівський, Г. Тарасов, В. Бутенко, Н. Долгая, В. Сухомлинський, К. Ушинський, Г. Шевченко).

Для того щоб існувати, люди повинні задовольняти різні потреби. Потреби - це усвідомлена необхідність у будь-чому, яка спонукає до дії; «необхідність, яка відчувається людиною в певних умовах життя та розвитку» [1, с. 186]. Будучи усвідомленими, потреби виявляються у формі мотивів поведінки. Потреби спонукають людину до активності. Так, у «Філософському енциклопедичному словнику» зазначається, що «потреби - ... внутрішній стимул активності» [10]. При цьому потреби впливають на переживання, мислення та волю людини. У зв'язку із задоволенням або незадоволенням потреб, залежно від засобів та способів їх задоволення людина переживає емоції напруги чи заспокоєння, задоволення чи незадоволення.

Найбільш відомими науковцями, які вивчали потреби i розробили теорії їх застосування, є А. Маслоу, Д. МакКеланд, Ф. Герцберг. Зокрема, одна з найвідоміших теорій потреб особистості була запропонована американським дослідником російського походження Абрахамом Маслоу. Визнаючи, що люди мають багато різноманітних потреб, він уважав, що їх можна згрупувати у п’ять основних категорій: 1) фізіологічні потреби (у їжі, воді, відпочинку тощо); 2) потреби в захисті від фізичних і психологічних переобтяжень; 3) соціальні потреби (приналежність до чогось або когось, прагнення соціальної взаємодії, підтримки); 4) потреби в повазі (прагнення до визнання власних досягнень оточуючими); 5) проблеми самовираження (реалізація своїх потенційних можливостей, удосконалення особистості) [5, с. 48]. Зазначимо, що в кожний конкретний момент часу людина буде прагнути до задоволення тієї потреби, яка є для неї важливішою і сильнішою. Перед тим, як потреба наступного рівня стане більш могутнім чинником поведінки людини, має бути задоволена потреба нижчого рівня.

Потреби, як невід’ємний компонент свідомості, виконують важливу роль в естетичному вихованні. Вони здатні регулювати спрямованість психічної діяльності індивіда. Характер потреб та їх регуляція залежать від цілісності психічного складу особистості, її вихованості. Потреби можуть бути усвідомленими або неусвідомленими, коли людина відчуває, що її «вабить невідома сила». Така потреба до сприйняття мистецтва може виникати навіть у непідготовленого реципієнта. При посиленні ваблення потреба усвідомлюється, оцінюється особистістю. При цьому санкціонується відповідна дія або гальмування.

Широта потреб залежить від рівня розвитку людини та матеріальних умов життя. Потреби людини різноманітні. Групуючи їх, можна виокремити матеріальні і духовні потреби. В основу такої класифікації покладено принцип спрямованості особистості на певний об’єкт. Різновидами художніх потреб є прикладні, пізнавальні й вищі (духовні) потреби [11, с. 48].

Духовні потреби людини - це потреба пізнати навколишній світ і самого себе, прагнення до самовдосконалення та самореалізації. Вони зумовлені внутрішнім світом людини, прагненням самозаглибитися, сконцентруватися на тому, що не пов’язано з її фізіологічними і соціальними потребами. Такі потреби спонукають до занять мистецтвом, культурою, релігією тощо заради прагнення зрозуміти вищий сенс свого існування. Загалом потреби людини можна уявити у вигляді піраміди, в основі якої лежать фізіологічні, а на ії 
вершині - духовні потреби. До духовних потреб відносяться: спілкування (обов’язки, права тощо), самовираження (в релігії, спорті, мистецтві, науці тощо), самоствердження (повага, визнання, влада тощо) [2, с. 10].

На думку М. Бережного, духовні потреби - специфічно людські потреби в пізнанні та естетичній насолоді. На основі потреби в пізнанні утворюється самостійна потреба у творчості. У цьому випадку пізнання стає не метою, а засобом задоволення потреби у творчості. Потреба в естетичній насолоді повинна посідати в житті людини певне місце. Споглядання естетичних цінностей в дійсності та мистецтві ошляхетнює особистість, підвищує її. Це споглядання може перетворитись на потребу художньої творчості [1, с. 19].

Дослідниками (М. Бережний, Б. Генкін, Л. Коган, О. Леонтьєв та інші) виокремлено більше сорока духовних потреб, серед них: потреба у пошуку сенсу життя, прагненні до досконалості, пізнанні навколишнього світу і свого місця в ньому, любові до ближнього, потреба в Істині, Добрі та Красі, духовного та соціального зростання, реалізації моральних цілей, емпатії до всього живого, потреба в духовному спілкуванні, високому ідеалі, найбільшій повноті життя й розширенні активності, прагненні бути тим, ким можеш стати.

Протягом століть людство визначило свої провідні духовні потреби. Вони також називаються вищими або загальнолюдськими цінностями, тому що $є$ важливими певною міврою для більшості людей. До загальнолюдських цінностей відносять, наприклад, категорії Любові, Щастя, Дружби; фізичне і психічне здоров’я, можливість насолоджуватися красою природи i мистецтва, мати цікаву роботу, займатися творчістю, вести активну життєдіяльність. Духовними потребами також уважаються свобода волі (як незалежність у своїх вчинках і діях) і впевненість у собі (як свобода від внутрішніх суперечностей).

Предметом духовної потреби є духовність. Проте, що таке духовність?

М. Бережний уважає, що духовність - це прагнення подолати себе у своїй свідомості, досягти високих цілей, слідувати особистому і суспільному ідеалу, загальнолюдським цінностям. Духовність виявляється також у прагненні до прекрасного, споглядання природи, класичних творів літератури та мистецтва [1, с. 52].

Духовному світові особистості, що формується, надавав великого значення В. Сухомлинський. Він розглядав формування духовного світу людини в тісному зв’язку як із його розумовим і фізичним, так і моральним та естетичним розвитком. Видатний педагог писав: «Сфера духовного життя людини - це розвиток, формування і задоволення ії моральності, інтелектуальних і естетичних запитів та інтересів у процесі активної діяльності. Джерелом духовного світу людини є матеріальний світ, об’єктивна дійсність і особливо такі важливі її сфери, як громадське життя людини, її соціальний і моральний досвід» [8, с. 224]. Духовний світ - це також своєрідний внутрішній всесвіт: почуття, емоції, прагнення, настрої, знання та переконання, ідеали, оцінки та уявлення про цінності. Духовний світ людини розглядається як діалектична єдність її раціональної, емоційно-чуттєвої та вольової сфер. Змістом духовного світу особистості, його багатством обумовлюється весь процес пізнання дійсності й самої людини.

Розв’язання проблеми формування духовних потреб учнів середніх класів спирається на методологічні засади. Постійне вдосконалення й наповнення новим змістом духовних потреб школярів можливе завдяки дії закону про велич потреб. За нашим переконанням, чим більше вживається духовних цінностей, тим вища творча активність учня, тим більше виникає нових духовних потреб. Духовні потреби характеризуються такими сутнісними рисами, як динамізм, можливість їх прогнозування і фазний характер.

Процес формування духовного світу здійснюється під впливом як комплексу дій, 
безпосередньо спрямованих на особистість, так і факторів, що впливають стихійно. У сучасних умовах середовище низкою своїх факторів здійснює натхненний вплив на людину. Невід’ємну, органічно цілісну частину цього середовища складає музичне мистецтво. Музичне мистецтво здатне сприяти інтенсивному зростанню духовності суспільства, що виявляється у створенні сприятливих передумов для реалізації музикою її потенційних можливостей. Вплив музики на людину полягає в якісних змінах складників естетичної свідомості, яка, на думку Л. Печко, охоплює «естетичне сприйняття, емоції, переживання й почуття, смак, потребу, оцінку й відношення, естетичний ідеал, естетичні погляди й теорії» [12, с. 76].

Г. Тарасов у праці «Проблеми духовної потреби» доходить висновків, що мають велике значення для нашого дослідження:

1. Показником музичного розвитку особистості $€$ iї здатність до відповідного музичного «опредмечування» своєї активності.

2. Успішне формування музичних потреб як специфічної форми активності особистості може здійснюватися при відповідності стану іï емоційно-ціннісної сфери сприйняттю ідейно-художнього рівня тих чи тих творів. Лише за цієї умови «зовнішнє» (у цьому випадку музичні впливи) можуть бути активно відображені «внутрішнім». Послідовна взаємодія особистості 3 музичним середовищем призводить до якісних змін ії музичної культури.

3. Музика - засіб для виклику й розвитку спонукальних можливостей кожного слухача, засіб об’єктивізації й актуалізації емоційного процесу його духовного життя.

4. Кінцевою метою спілкування з музикою постає пізнання слухачами того соціально значущого для них буття, специфічною формою відображення якого вона є. Тільки ті музичні ідеї, почуття й образи, які, схвилювавши емоційно-ціннісну сферу індивіда, в змозі мотивувати його естетичну діяльність, здатні також спонукати й захований раніше потенціал відповідних сутнісних сил особистості, стимулюючи тим самим зростання і духовний розвиток [9, с. 73-74].

Незважаючи на великий обсяг наукових досліджень, присвячених проблемі формування духовних потреб учнів, недостатньо вивченим залишається питання використання комплексу мистецтв у практиці викладання музичного мистецтва в загальноосвітній школі.

Проблема комплексу мистецтв, міжпредметних зв’язків, інтегрованих курсів останні десятиліття активно привертає увагу дослідників у сфері педагогіки мистецтва і на різних концептуальних i методичних засадах розв'язується щодо початкової (Н. Аніщенко, Е. Бєлкіна, Л. Масол, Т. Науменко, Б. Юсов), основної (П. Волкова, Ю. Солодовніков, Г. Шевченко), старшої школи (Л. Предтеченська, Л. Рапацька, Н. Фунтікова), а також в умовах професійної педагогічної освіти (О. Бузова, Л. Кондрацька, Г. Падалка, Т. Рейзенкінд, І. Хімік, О. Щолокова та ін.) [6, с. 32].

Провідним педагогічним принципом у таких аспектах мистецької освіти, як вивчення одного з видів мистецтва, їх комплексу та художнього синтезу, є усвідомлення і засвоєння специфіки художньої мови і прийомів створення художнього образу. Адже під час опанування окремого мистецтва відбувається накопичення знань про засоби виразності в одному з видів творчості. «Дуже важливо, - писав Д. Кабалевський, - щоб у свідомості дітей музика не стояла осторонь від інших мистецтв, а якомога яскравіше виявляла свої глибокі внутрішні (а не лише зовнішньо-сюжетні) зв’язки з ними» [3, с. 110].

Поняття «комплекс мистецтв» у педагогічному аспекті розуміють як системне 
поєднання різних видів мистецтва в межах однієї навчальної дисципліни задля долучення учнів до різних видів музично-естетичної діяльності. Головна мета використання комплексу мистецтв на уроках музичного мистецтва полягає в розвитку художнього світогляду, вихованні естетичної та моральної свідомості учнів, формуванні їхньої пізнавальної активності. Отже, варто розглядати комплекс мистецтв як систему педагогічних дій, що здійснюють істотний вплив на формування духовних потреб і загальний розвиток учнів середніх класів за умови врахування мотивів, їхніх індивідуальних якостей, психічних станів.

Слід зазначити, що світ мистецтва репрезентований у сучасних шкільних програмах трьома його видами - літературою, музикою, образотворчим мистецтвом, які займають центральне місце в художній культурі. Так, література найповніше і найглибше втілює життя, думки людини, музика - життя ï почуттів і переживань, образотворче мистецтво зміст уявлень людини про світ у тій формі, яку дає їй реальне почуттєве сприйняття дійсності. Тим самим музика, література й образотворче мистецтво всебічно й повно охоплюють духовне життя людини, а їх різні поєднання дають змогу передати взаємозв’язок процесів, що відбуваються в ньому.

Визначаючи інтегрований взаємозв’язок різних видів мистецтва на уроках музики як одну $з$ основних умов керівництва музичним сприйманням школярів, а також як засіб формування їхніх духовних потреб, науковці виходять 3 того, що доцільне використання художніх творів різних видів мистецтва надасть можливість учителю розв'язувати складні завдання наведення учнів на естетичне осягнення і переживання змісту музики з опорою на весь художній досвід дітей без нав’язливого або грубого втручання в цю тонку сферу художньої діяльності людини.

Як показує досвід, між видами мистецтва існує не лише сюжетний або хронологічний зв’язок, а й внутрішній, творчий і життєвий. I це зрозуміло, адже усі види мистецтва народжуються з єдиного джерела - реального життя, яке однаковою мірою живить творчість i композитора, і письменника, і художника. Отже, взаємозв'язок між видами мистецтва означає не лише знаходження внутрішніх зв’язків між музикою, літературою й живописом, а й між цими видами мистецтва і життям [4, с. 28].

На думку О. Рудницької, комплексне використання дає можливість осягнути i зіставити різні художні мови, що створює основу для активізації уяви, асоціативного мислення, збагачення чуттєвої сфери сприйняття мистецтв. До комплексного використання різних видів мистецтва слід віднести спроби сюжетного прочитання дитячої програмної музики на екрані, її демонстрації у зорових, художніх образах. Прикладом такої інтеграції візуального і слухового рядів є музичні мультфільми («Дитячий альбом» П. Чайковського, «Картинки з виставки» М. Мусоргського», «Танок ляльок» Д. Шостаковича), які акцентують емоційну увагу юного слухача на глибині і змістовності засобів музичної виразності, допомагають набути досвіду їх сприйняття [7, с. 124].

Останнім часом розробляються і впроваджуються у шкільну практику нові програми 3 образотворчого мистецтва і музики, у яких автори прагнуть відобразити тенденцію до комплексу видів мистецтва. Так, оригінальні моделі художньо-педагогічної організації змісту інтегративного курсу пропонують автори програм 3 художньої культури (Л. Кондрацька, Л. Предтеченська, О. Щолокова та ін.), більшість із яких грунтуються на комплексі словесної, музичної і візуальної творчості та побудовані переважно за хронологічним (циклічним, цивілізаційним) принципом.

Найпопулярнішою є тематична (сюжетна) інтеграція, коли навчальний матеріал добирається за принципом зовнішньої формальної спорідненості образів і тем художніх 
творів - поетичних, музичних і візуальних. Хрестоматійним прикладом, яких можна навести чимало, є така тріада: п’єса П. Чайковського «Осіння пісня» 3 циклу «Пори року» - вірш О. Пушкіна «Унылая пора, очей очарованье...»- картина І. Левітана «Осінь». Існує досвід використання колекції з художніх творів, які об’єднані в блоки за естетичними категоріями («героїчне», «ліричне», «епічне», «трагічне» тощо) або за емоційно-образною спорідненістю образів («сум», «радість» тощо).

Доречними будуть інтегровані уроки під час опанування спільних для всіх видів мистецтва тем «Весняні настрої» (осінні, зимові, літні), «Образи природи», «Героїчні мотиви» тощо. Інтеграторами в таких мистецьких комплексах стають суголосні естетичні почуття, образи-аналогії, втілені різними художніми засобами.

Зазначимо, що комплекс мистецтв, здійснюючи всебічний вплив на учнів середніх класів, є ефективним засобом духовного виховання на уроках музичного мистецтва. Задля досягнення цієї мети вчителеві варто застосовувати методи бесіди, порівняння різних творів мистецтва, проведення аналогій між їх виражальними засобами, емоційно-образної драматургії, створення проблемних ситуацій, що сприятиме не лише накопиченню відповідних знань та вмінь, а й формуванню духовних потреб учнів, розвитку вміння бачити всю систему художніх взаємозв’язків у мистецтві, простежувати моменти органічного поєднання мистецтва з життям.

Формуючи духовні потреби учнів, учителям музичного мистецтва доцільно проводити уроки з тем: «Аве Марія», «Кривавим сном одкорчилась війна», «Пісні-символи», «Піднесеність бахівських образів», «Глибина та виразність образів природи у вокальній музиці», «Образ Батьківщини в музиці» та інші.

Формування духовних потреб учнів середніх класів відбувається під час виконання тестових завдань, слухання музичних творів, розгляду творів образотворчого мистецтва, читання уривків з літературних творів та їх аналізу, виконання музичних, пластичних імпровізацій, а також під час виконання таких творчих завдань: 1) «озвучити» скульптуру Мікеланджело «П’єта»; 2) підібрати музику, співзвучну повісті Б. Васильєва «Не стріляйте в білих лебедів» та визначити ідейно-художній задум письменника; 3) дібрати до одного 3 сонетів В. Шекспіра музичний фрагмент, який би розкривав ідейно-художній задум драматурга; 4) через рухи й пластику виконати безсловесний аналіз музичного твору, «проживання» художнього образу; 5) визначити характер звучання, особливості тематизму, форми, жанру триголосної інвенції Й. С. Баха № 15 h-moll; 6) бесіда за круглим столом на тему «Мої роздуми про духовну музику»; 7) дібрати музичний фрагмент до скульптурної композиції В. Сидура «Пам’ятник загиблим від насильства», який найяскравіше передає ідейно-художній задум скульптора; 8) виконати народну пісню, яка була б співзвучна картині І. Репіна «Бурлаки на Волзі»; 9) дібрати до музичного та живописного твору «Володимирка» (І. Шамо - І. Левітан) вірш або уривок з прозового твору, який би розкривав ідейно-художній задум майстрів тощо.

Отже, комплекс мистецтв є вагомим чинником впливу на розвиток емоційної сфери, формування духовних потреб учнів середніх класів, яке в навчальному процесі відбувається на досить широкому матеріалі творів мистецтва (музики, живопису, скульптури, літератури). У процесі засвоєння цього матеріалу, створення цілої низки емоційних ситуацій школярі мають можливість співпереживати почуттям, настроям героїв творів та їх автора, зрозуміти його ідеї, виразити власні почуття й думки, самостійно аргументувати морально-естетичну оцінку музичних образів, які резонують з аналогічними образами в інших видах мистецтва.

Проведене дослідження не вичерпує всіх аспектів проблеми. Зазначені шляхи 
формування духовних потреб школярів засобами комплексу мистецтв потребують більш детального розгляду в подальших наукових дослідженнях.

\section{Література}

1. Бережной Н. М. Человек и его потребности / Николай Михайлович Бережной; [под ред. В. Д. Диденко]. - Москва : Московский государственный университет сервиса, 2000. 210 с. 2. Духовность, художественное творчество, нравственность (материалы «круглого стола») // Вопросы философии. - 1996. - № 2. - С. 9-12. 3. Кабалевский Д. Б. Эстетическая культура и школа / Д. Б. Кабалевский // Советская педагогика. - 1970. - № 1. - С. 24-25. 4. Каган М. С. Роль и взаимодействие искусств в педагогическом процессе / М. С. Каган // Музыка в школе. - 1984. - № 4. - С. 28-32. 5. Маслоу А. Дальние пределы человеческой психики: [монография]/ Абрахам Маслоу; [пер. с англ.]. - Санкт-Петербург : Евразия, 1997. - 430 с. 6. Методика навчання мистецтва у початковій школі : [посібник для вчителів] / [под ред. Л. М. Масол]. - Харків : Ранок, 2006. - 256 с. 7. Рудницька О. П. Педагогіка: загальна та мистецька: [навч. посібник] / Оксана Петрівна Рудницька. - Київ : Знання, 2002. 270 с. 8. Сухомлинский В. А. Духовный мир школьника / Василий Александрович Сухомлинский // Избранные произведения: в 5-ти томах. - Київ : Радянська школа, 1979. - Т. 1. - 568 с. 9. Тарасов Г. С. Психология музыкального воспитания школьников / Г. С. Тарасов // Вопросы психологии. - 1991. - № 1. - C. 58-74. 10. Философский энциклопедический словарь / [под ред. И. Т. Фролова]. - Москва : Политиздат, 1987. - 590 с. 11. Шаров Ю. В. О сущности, специфике и классификации духовных потребностей / Юрий Владимирович Шаров // Проблемы формирования социогенных потребностей: материалы I Всесоюзной конференции (Тбилиси, 4-5 ноября 1974 г.). - Тбилиси. - С. 47-49. 12. Шульженко А. Н. Гносеологические основы музыкально-эстетического воспитания: [учебн. пособие для студ. муз.-пед. фак-тов] / Алим Никитович Шульженко. - Москва : Просвещение, 1992. - 236 с.

\section{ПІДГОТОВКА МАЙБУТНІХ УЧИТЕЛІВ ДО ОРГАНІЗАЦІЇ МОРАЛЬНОГО ВИХОВАННЯ УЧНІВ}

Підборський Ю. Г. Підготовка майбутніх учителів до організації морального виховання учнів.

У статті розглнуто питання підготовки майбутніх учителів до організації морального виховання у загальноосвітній школі, а також питання підготовки нової генерації педагогічних кадрів. Розкрито особливості діяльності суб’єктів морального виховання; шляхи максимальної активізації учнів як суб’єктів навчально-виховного процесу; форми і методи виховання, які грунтуються на гуманних стосунках педагогів і учнів.

Ключові слова: учителі, професійна підготовка вчителя, моральне виховання учнів, загальноосвітня школа.

Підборський Ю. Г. Подготовка будущих учителей $\quad$ к организации нравственного воспитания учащихся.

В статье рассматриваются вопросы подготовки будущих учителей к организации нравственного воспитания в общеобразовательной школе, а так же вопросы подготовки новой генерации педагогических кадров. Раскрыты особенности деятельности субъектов 